\title{
Crosstalk between PDGF and IGF-I receptors in rat liver myofibroblasts: implication for liver fibrogenesis
}

\author{
Ruslan Novosyadlyy*, Jozsef Dudas, Rajeswararao Pannem, Giuliano Ramadori \\ and Jens-Gerd Scharf \\ Department of Medicine, Division of Gastroenterology and Endocrinology, Georg-August-Universität, \\ Göttingen, Germany
}

\begin{abstract}
Insulin-like growth factor I (IGF-I) and platelet-derived growth factor (PDGF) have been identified as significant mitogens for liver myofibroblasts (LMFs), one of the cell populations playing a role in liver fibrogenesis. In the present work, we aimed to elucidate a possible interaction between PDGF receptor (PDGFR) and IGF-I receptor (IGF-IR) signaling in LMFs. Among different rat liver cells, PDGFR $\alpha$ - and $\beta$-subunits were mainly expressed in hepatic stellate cells and LMFs, and were upregulated during their in vitro cultivation. In LMFs, PDGF-BB $(10 \mathrm{ng} / \mathrm{ml})$ stimulated DNA synthesis approximately two-fold and this effect was similar to that of IGF-I. IGF-I and PDGF-BB differentially affected IGF-IR and PDGFR signaling. High concentrations of IGF-I decreased levels of IGF-IR and IRS-1 and inhibited the expression and activation of PDGFR $\alpha$. PDGF-BB prevented IGF-I-induced downregulation of the IGF-IR, but did not affect expression of its cognate receptor subunits. Transphosphorylation of PDGFR and IGF-IR was not observed. PDGF effectively activated terminal MAP kinases, PI3 kinase and Akt kinase, whereas IGF-I demonstrated weaker effects. PLC $\gamma_{1}$ was phosphorylated only in response to PDGF, but not to IGF-I. In rat LMFs, blockade of the IGF-IR via inhibition of the IGF-IR kinase completely abrogated IGF- and PDGF-induced mitogenesis and the ability of PDGF to phosphorylate PLC $\gamma_{1}$. In conclusion, the presented data demonstrate that the PDGFR signaling requires a functional IGF-IR and that PDGF-BB stabilizes the IGF-IR function through preventing the IGF-I-induced downregulation of the IGF-IR. These interactions might be relevant in vivo for the fibroproliferative response during liver injury.
\end{abstract}

Laboratory Investigation (2006) 86, 710-723. doi:10.1038/labinvest.3700426; published online 8 May 2006

Keywords: liver fibrogenesis; IGF; PDGF; receptors; crosstalk

Liver fibrosis results from excessive accumulation of extracellular matrix which is mainly produced from cells of the fibroblast lineage. ${ }^{1,2}$ Recent studies demonstrated that different liver cell populations are involved in this process: activated hepatic stellate cells (HSCs) as well as portal and perivascular liver myofibroblasts (LMFs) which represent morphologically and functionally different fibroblast populations. ${ }^{3-6}$ While HSCs and LMFs are capable to synthesize a broad spectrum of extracellular matrix proteins during liver injury, both

Correspondence: Dr J-G Scharf, MD, Medizinische Universitätsklinik, Robert-Koch-Strasse 40, D-37075 Göttingen, Germany. E-mail: jscharf@med.uni-goettingen.de

${ }^{*}$ Current address: Division of Endocrinology, Diabetes and Bone Diseases, The Samuel Bronfman Department of Medicine, Mount Sinai School of Medicine, New York, NY, USA.

Received 16 September 2005; revised 16 March 2006; accepted 20 March 2006; published online 8 May 2006 liver cell types reveal striking differences in their cell biology including cell proliferation and lifespan. Activated HSCs in vivo and in vitro undergo spontaneous apoptosis while LMFs in culture are highly proliferative and can be passaged for several times. ${ }^{1}$

Among different cytokines and growth factors, IGF-I and PDGF have been identified as important mitogens for LMFs in vitro. ${ }^{7,8}$ The biological effects of IGF-I are mediated via the IGF-I receptor (IGF-IR), which belongs to the family of receptor tyrosine kinases. Upon ligand binding and receptor autophosphorylation, the IGF-IR recruits and activates particular adaptor proteins, known as insulin receptor substrates (IRS). IRS bring together and coordinate the activity of other signaling intermediates, finally resulting in activation of two principal signaling pathways including mitogenactivated protein kinase (MAPK) pathway that plays a pivotal role in cell growth and proliferation, and 
phosphatidylinositol-3,4,5-triphosphate kinase (PI3K) pathway, which is mainly involved in mediating the metabolic, antiapoptotic and other more differentiated effects of IGF-I. ${ }^{9,10}$ Formerly, several studies have pointed to interactions between the IGF-IR and other growth regulatory signals including plateletderived growth factor (PDGF). In human skin fibroblasts, PDGF stimulated synthesis of IGF-I and increased the number of IGF-I binding sites. ${ }^{11,12}$ In addition, further studies revealed that PDGF also stimulated IGF-IR mRNA expression through activation of the IGF-IR gene promoter. ${ }^{13}$ The concept of a IGF-IR/PDGF receptor (PDGFR) interaction was further supported by experiments showing that fibroblasts isolated from mice with a targeted disruption of the IGF-IR gene failed to proliferate in response to $\mathrm{PDGF}{ }^{14}$

In terms of liver fibrogenesis, the interaction between the IGF-IR and the PDGFR signaling systems appears to be of particular interest because in vitro both IGF-I and PDGF have been demonstrated to potentiate the mitogenic effects of each other in fibroblast cultures. ${ }^{10,15}$ Therefore, in the current work, we aimed to highlight the molecular mechanisms of the possible crosstalk between the PDGFR and IGF-IR signaling systems in rat LMFs with particular emphasis on its implication for liver fibrogenesis.

\section{Materials and methods}

\section{Materials}

Chemicals and materials were obtained from commercial sources as indicated: PD98059, SP600125 (Alexis, Grünberg, Germany), [ $\left.{ }^{32} \mathrm{P}\right]$-labeled deoxycytidine-triphosphate (specific activity $3000 C_{\mathrm{i}}$ / $\mathrm{mmol} / \mathrm{l}$ ), protein A sepharose 4 fast flow, Rainbow ${ }^{\mathrm{TM}}$ colored protein molecular weight markers, Hybond membranes, X-ray films Hyperfilm ${ }^{\mathrm{TM}}$ (Amersham Biosciences, Freiburg, Germany); fetal bovine serum (Biochrom, Berlin, Germany); I-OMe-AG 538, LY294002, m-3M3FBS, SB203580, U73122 (Calbiochem, San Diego, CA, USA); Nick translation kit (Invitrogen, Karlsruhe, Germany); Akt kinase assay kit (Cell Signaling, Beverly, MA, USA); pronase E, penicillin G, streptomycin, sodium fluoride (Merck, Darmstadt, Germany); pentobarbital-sodium (Merial, Hallbergmoos, Germany); NEBlot ${ }^{\circledR}$ kit (New England Biolabs, Schwalbach, Germany); human growth hormone (Nordisk, Mainz, Germany); Nycodenz (Nyegaard, Oslo, Norway); Dulbecco's modified Eagle medium (DMEM), trypsin, bovine serum albumin, L-glutamine (PAA, Linz, Austria); recombinant human IGF-I (PeproTech, Rocky Hill, NJ, USA); BCA protein assay, SuperSignal ${ }^{\circledR}$ West Pico chemiluminescent substrate (Pierce, Bonn, Germany); DNase I, collagenase H, CHAPS, BrdU labeling and detection kit III (Roche, Mannheim, Germany); nitrocellulose membranes (Sartorius, Göttingen, Germany); Tween 20 (Serva,
Heidelberg, Germany); recombinant rat PDGF-BB, porcine insulin, collagenase type I, protease inhibitors, sodium orthovanadate, tetrasodium pyrophosphate, $\beta$-glycerophosphate (Sigma, Munich, Germany); hybridization solution QuikHyb (Stratagene, Heidelberg, Germany).

\section{cDNA Probes}

The following cDNA probes were used for Northern blot analysis: a 265 bp fragment of rat IGF-IR cDNA provided by Drs LeRoith and Roberts (Bethesda, MD, USA), a $308 \mathrm{bp}$ fragment of rat PDGFR $\alpha$ cDNA generated by PCR using rat olfactory epitheliumderived cDNAs as a template,$^{16}$ a $363 \mathrm{bp}$ fragment of rat PDGFR $\beta$ cDNA generated by PCR using rat brainderived cDNAs as a template. ${ }^{17}$ An oligonucleotide $5^{\prime}$ AAC GAT CAG AGT AGT GGT ATT TCA CC $3^{\prime}$ complementary to the $28 \mathrm{~S}$ ribosomal RNA (rRNA) (MWG Biotech, Ebersberg, Germany) was used to quantify Northern blots.

\section{Antibodies}

The following antibodies and sera were purchased from commercial sources as indicated: rabbit polyclonal antisera against the IGF-IR $\beta, \operatorname{PDGFR} \beta$, PDGFR $\alpha$, IRS- 1 and PLC $\gamma_{1}$, goat polyclonal antiserum against IRS-2 and phospho-PDGFR $\alpha$ (Tyr 720) (Santa Cruz Biotechnology, Santa Cruz, CA, USA), rabbit polyclonal antiserum against Gab-1 (Upstate Biotechnology, Lake Placid, NY, USA), mouse monoclonal antiphosphotyrosine antibody (PY20) (Oncogene, San Diego, CA, USA), mouse phosphoERK1/2 (Thr202/Tyr204), phospho-SAPK/JNK (Thr183/Tyr185), phospho-p38 kinase (Thr180/ Tyr182) monoclonal antibodies and rabbit phospho-(Tyr) p85 PI3K-binding motif polyclonal antibodies (Cell Signaling, Beverly, MA, USA), mouse monoclonal antibody raised against $\beta$-actin (Sigma), secondary peroxidase-conjugated antibodies (DAKO, Copenhagen, Denmark).

\section{Animals}

Adult Wistar rats were purchased from Winkelmann (Borchen, Germany) and kept under standard conditions with 12-h light/dark cycles and access to fresh water and food pellets ad libitum. All animals received humane care in compliance with the institutional guidelines, the German Convention for Protection of Animals and the National Institutes of Health guidelines.

\section{Isolation and Culture of Rat Liver Cells}

Rat hepatocytes were isolated through circulating perfusion with collagenase as described previously ${ }^{18}$ with slight modifications. ${ }^{19}$ Cells were 
cultured as reported before. ${ }^{20}$ Rat Kupffer cells were isolated by centrifugal counterflow elutriation according to Knook and Sleyster ${ }^{21}$ and were cultured as described formerly. ${ }^{19}$ HSCs were isolated from rat liver and kept in primary culture according to the method of Knittel et al. ${ }^{22}$ Isolation and culture of rat LMFs was essentially carried out as reported recently. ${ }^{3,7}$ The experiments in the present study were performed on cultures of LMFs between passages 1 and 10 using at least three independent cell isolations.

\section{Treatment of Rat LMFs}

Rat LMFs were allowed to grow until $80 \%$ confluence. Before the addition of stimuli, cultures of rat LMFs were washed in phosphate-buffered saline (PBS), maintained in serum-reduced culture medium (DMEM) supplemented with $0.3 \%$ FCS for $1 \mathrm{~h}$, and incubated then in the presence or absence of growth factors and inhibitors or activators of signal transduction pathways. Pharmacological inhibitors I-OMe-AG 538, LY294002, PD98059, SB203580, SP600125, U73122 and phospholipase C activator m-3M3FBS diluted in dimethylsulfoxide (DMSO) were used. All cultures received the same amount of solvent. In parallel, Trypan blue staining was performed to rule out cell toxicity due to the inhibitors or DMSO. Alternatively, in order to study the phosphorylation of the IGF-IR, PDGFR and their signaling intermediates, cell starvation and treatment of cells were performed under serum-free conditions. After treatment, cells were rinsed in cold PBS and immediately were used for RNA isolation and protein extraction.

\section{Isolation of Total RNA and Northern Blot Analysis}

Total cellular RNA was isolated from monolayers of rat liver cells by means of guanidine isothiocyanate extraction, cesium chloride density-gradient ultracentrifugation and ethanol precipitation according to the method of Chirgwin et al. ${ }^{23}$ Northern blot analysis was essentially carried out as described before. $^{7}$

\section{Protein Extraction and Western Blot Analysis}

After treatment, cultures of rat LMFs were washed once with ice-cold PBS and solubilized in lysis buffer (pH 7.4) containing $50 \mathrm{mM}$ Tris, $150 \mathrm{mM}$ NaCl, 1 mM EDTA, 1\% CHAPS, 1 mM phenylmethanesulfonyl fluoride, $1 \mathrm{mM}$ benzamidine, $8.25 \mathrm{mM}$ chymostatin, $1 \mu \mathrm{g} / \mathrm{ml}$ pepstatin A, $1 \mu \mathrm{g} / \mathrm{ml}$ leupeptin, $1 \mu \mathrm{g} / \mathrm{ml}$ antipain, $1 \mathrm{mM}$ sodium orthovanadate, $2 \mathrm{mM}$ sodium fluoride, $10 \mathrm{mM}$ sodium pyrophosphate and $8 \mathrm{mM} \beta$-glycerophosphate. Solubilized cells were harvested by scraping and incubated on ice for $30 \mathrm{~min}$. For better homogenization, cell lysates were passed through $24 \mathrm{G}$ injection needle. The insoluble material was removed by centrifugation at $10000 \times g$ for $10 \mathrm{~min}$ at $4^{\circ} \mathrm{C}$. Concentrations of cellular proteins in the supernatants were further determined by BCA protein assay (Pierce) using bovine albumin as a protein standard. Cell lysates were subjected to electrophoresis and immunoblotting or were used for immunoprecipitation. For WB analysis, $10-50 \mu \mathrm{g}$ of cell lysates were resuspended in sample buffer, denatured by boiling at $95^{\circ} \mathrm{C}$, subjected to SDS-PAGE (6-10\% acrylamide), and transferred to nitrocellulose membrane. The membrane was then sequentially probed with primary and secondary antibodies, incubated with SuperSignal ${ }^{\circledR}$ West Pico chemiluminescent substrate, and exposed to X-ray films. Equal loading of proteins was confirmed by immunoblotting with antibodies directed against $\beta$-actin.

\section{Immunoprecipitation}

Cell lysates containing equal amounts $(500 \mu \mathrm{g})$ of protein were mixed with antibodies ( $5 \mu \mathrm{g}$ of antibody per sample) and incubated overnight at $4^{\circ} \mathrm{C}$ with slight agitation. The immune complexes were then incubated with $100 \mu \mathrm{l}$ of $30 \%$ protein A sepharose bead slurry (30 $\mu$ l of packed beads) for $4 \mathrm{~h}$ at $4^{\circ} \mathrm{C}$. Subsequently, sepharose beads were collected by centrifugation at $16500 \times g$ for $1 \mathrm{~min}$. The supernatant was carefully removed, the pellet was washed three times with $500 \mu \mathrm{l}$ of ice-cold $50 \mathrm{mM}$ Tris buffer ( $\mathrm{pH}$ 7.4), and the proteins were resuspended in $35 \mu \mathrm{l}$ of $2 \times$ sample buffer and boiled at $95^{\circ} \mathrm{C}$ for $5 \mathrm{~min}$. Finally, dissociated sepharose beads were pelleted by pulse centrifugation at $16500 \times g$ for $30 \mathrm{~s}$. Immunoprecipitates were then size-fractionated by SDS-PAGE and transferred to nitrocellulose membrane. To detect tyrosine phosphorylation of precipitated proteins, the membrane was subjected to immunoblotting with monoclonal mouse antiphosphotyrosine antibody as described above. To ensure equal loading of the precipitated protein, after evaluation of tyrosine phosphorylation the membrane was stripped of immunoglobulin and reprobed with an antibody used for protein precipitation.

\section{Akt Kinase Assay}

Akt kinase activity was determined by a commercially available kit according to the instructions of the manufacturer. In brief, Akt was immunoprecipiated from cell lysates of LMFs treated with the indicated growth factors for $10 \mathrm{~min}$ under serumfree conditions by an immobilized Akt monoclonal antibody followed by an in vitro kinase assay using GSK-3 fusion protein as a substrate. Phosphorylation of GSK-3 was measured by WB analysis using a phospho-GSK-3 $\alpha / \beta$ antibody. 


\section{Determination of DNA Synthesis}

DNA synthesis in cultures of rat LMFs was evaluated by BrdU labeling as described recently. ${ }^{7}$ The BrdU incorporation assay was performed in quadruplicate using at least three independent isolations of LMFs.

\section{Statistical Analysis}

All experiments were replicated three- to four times. Results of the BrdU incorporation assay are expressed as the percentage of incorporation \pm standard error of the mean (s.e.m.) relative to the control. Representative autoradiographs of Western and Northern blots at least three independent experiments are presented. Autoradiographs were scanned (Bio-Rad, Hercules, CA, USA). After background subtraction, densitometry of individual bands was analyzed by ImageJ software (Version $1.34 \mathrm{~s}$, NIH, Bethesda) according to the instructions of the manual. Statistically significant differences of experiments with multiple comparisons were determined by ANOVA.

\section{Results}

\section{Expression of PDGF Receptors}

PDGF receptor expression in rat liver was evaluated by Northern blot analysis using total RNA isolated from different rat liver cells. Transcripts encoding rat $\operatorname{PDGFR} \alpha$ were detected at 6.5 and $4.7 \mathrm{~kb}$, respectively, and mRNA species specific for rat PDGFR $\beta$ at $5.4 \mathrm{~kb}$ (Figure 1a). Total RNA obtained from hepatocytes showed no hybridization signals with the $\left[{ }^{32} \mathrm{P}\right]$-labeled PDGFR $\alpha$ and PDGFR $\beta$ probes. In total RNA obtained from KCs only mRNA species coding for the PDGFR $\alpha$ were detected. Transcripts encoding both PDGFR $\alpha$ and $\operatorname{PDGFR} \beta$ were highly abundant in LMFs and HSCs. PDGFR expression of LMFs and HSCs was upregulated with time of culture. In LMFs, PDGFR expression was maximal at days 10 and 14 of culture when cells were confluent. Increased PDGFR mRNA expression in cultures of LMFs had direct functional consequences. As demonstrated by BrdU incorporation assay, PDGF-BB stimulated DNA synthesis in LMFs, and this stimulatory effect was more pronounced in LMFs treated 48-72 h after plating than at earlier time points of culture (Figure 1b).

\section{Effect of IGF-IR Blockade on IGF-I- and PDGF-Stimulated DNA Synthesis}

To test whether a functional IGF-IR is required for mitogenic activity of PDGF in LMFs, the effect of tyrphostin I-OMe-AG 538, a selective inhibitor of the IGF-IR kinase, on PDGF-induced mitogenic activity was evaluated by BrdU incorporation.
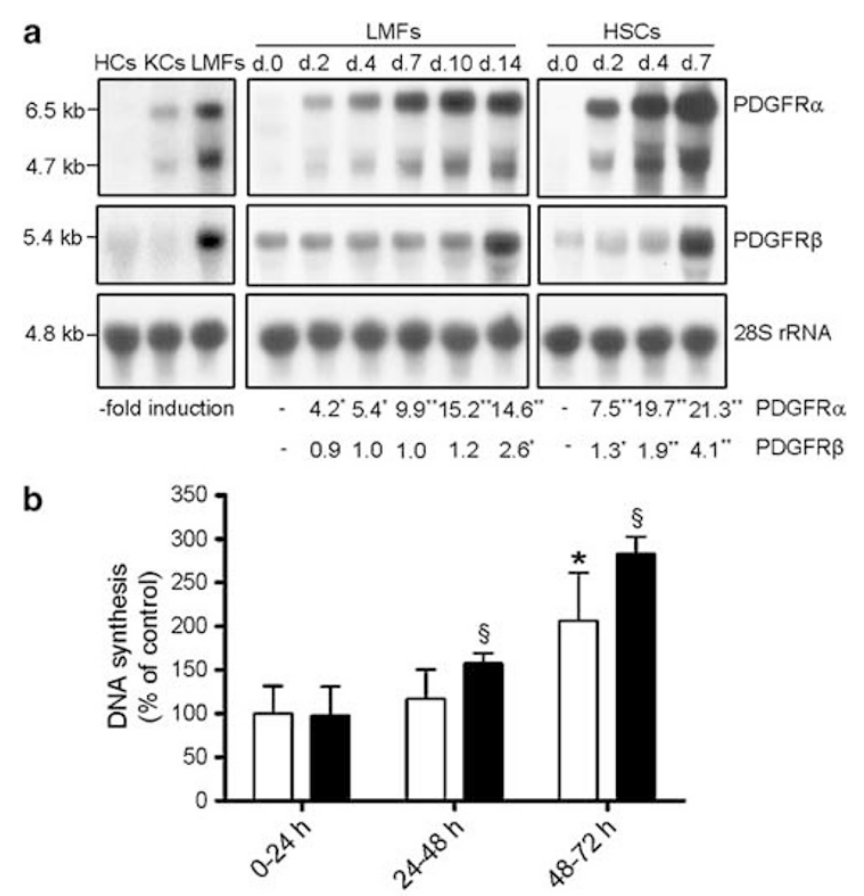

Figure 1 PDGF receptors mRNA expression in LMFs (a). Upper parts: $10 \mu \mathrm{g}$ of total RNA obtained from rat hepatocytes (HCs), Kupffer cells (KCs), liver myofibroblasts (LMFs) and hepatic stellate cells (HSCs) at different days (d) of culture were separated by $1 \%$ agarose gel electrophoresis, blotted and probed for rat PDGFR $\alpha$ and PDGFR $\beta$, respectively. Cultures of LMFs became confluent between day 7 and 10 of culture. Equal loading of RNA was demonstrated after stripping and rehybridization of membranes with an oligonucleotide complementary to $28 \mathrm{~S}$ rRNA. The sizes of the hybridization bands (in kb) are indicated on the left. Hybridization signals were densitometrically analyzed and indicated as fold increase or decrease compared with PDGFR mRNA expression at day 0 . Statistically significant differences in PDGFR expression are indicated: ${ }^{*} P<0.05$, ${ }^{*} P<0.01$ by ANOVA. Effect of cell density on mitogenic response to PDGF-BB in rat LMFs (b). Cultures of LMFs at different time points after plating were incubated in the presence or absence of PDGF-BB $(10 \mathrm{ng} / \mathrm{ml})$ for $24 \mathrm{~h}$. DNA synthesis was evaluated by BrdU incorporation assay. Results are expressed as the percentage of incorporation \pm s.e.m. relative to the untreated control $(n=3$ independent experiments performed in quadruplicate). Statistically significant difference: $P<0.001$ vs untreated control cultures $\left({ }^{*}\right)$ or PDGF-BB treated subconfluent cultures (§).

Recombinant PDGF-BB stimulated DNA synthesis in LMFs and this effect was similar to that of IGF-I. Coincubation of LMFs with PDGF-BB and IGF-I further increased their mitogenic effects. Inhibition of the IGF-IR kinase with tyrphostin I-OMe-AG 538 significantly impaired IGF-I- and PDGF-induced mitogenesis in cultures of rat LMFs (Figure 2a). Nonspecific inhibition of PDGFR $\beta$ by I-OMe-AG 538 was excluded since PDGF-induced phosphorylation of the PDGFR $\beta$ remained unaffected in the presence of this tyrphostin (Figure $2 \mathrm{~b}$ ). In a second approach, IGF-IR was blocked with anti-IGF-IR $\beta$ antibodies that also resulted in the inhibition of both IGF-I- and PDGF-induced DNA synthesis (Figure 2a). Thus, presence of the IGF-IR appears to be necessary for PDGF-induced mitogenic activity in LMFs. 
a

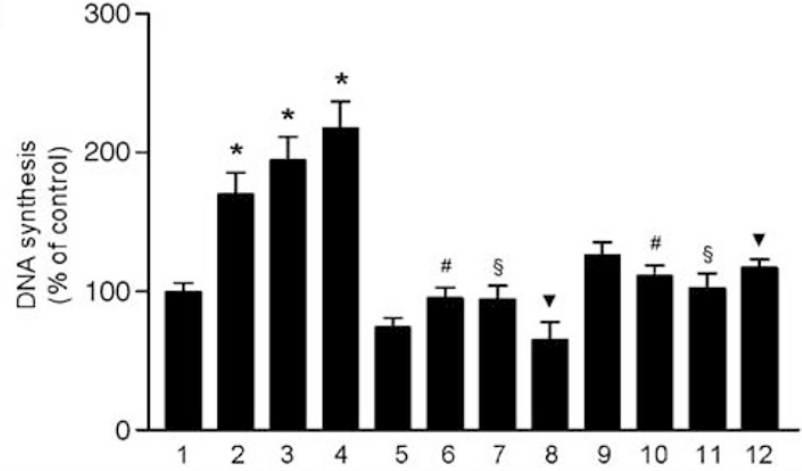

b

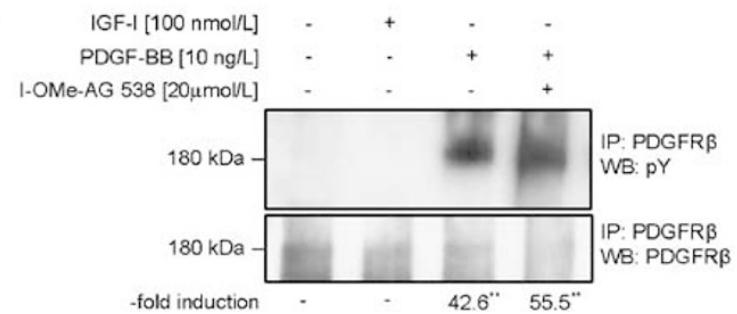

Figure 2 Effect of IGF-IR blockade on IGF-I- and PDGF-stimulated DNA synthesis in LMFs (a). After starvation in serum-reduced DMEM for $1 \mathrm{~h}$, cells were incubated for $24 \mathrm{~h}$ with IGF-I $(100 \mathrm{nmol} /$ l) and/or PDGF-BB $(10 \mathrm{ng} / \mathrm{ml})$ in the presence or absence of tyrphostin I-OMe-AG $538(20 \mu \mathrm{mol} / \mathrm{l})$, a selective inhibitor of the IGF-IR tyrosine kinase or anti-IGF-IR $\beta$ antibodies $(1 \mu \mathrm{g} / \mathrm{ml})$. Control cultures were maintained in serum-reduced DMEM for $24 \mathrm{~h}$. All cells received the same amount of DMSO. DNA synthesis was evaluated by BrdU incorporation assay. Results are expressed as the percentage of incorporation \pm s.e.m. relative to the control ( $n=3$ independent experiments performed in quadruplicate). Statistically significant difference: $P<0.05$ vs untreated control cultures $\left({ }^{*}\right)$ or IGF-I $(\#)$, PDGF-BB $(\S)$ and IGF-I/PDGF-BB $(\boldsymbol{\nabla})$ treated cultures. Effect of tyrphostin I-OMe-AG 538 on PDGFinduced phosphorylation of PDGFR $\beta$ (b). Subconfluent cultures of LMFs were maintained in serum-free DMEM for $1 \mathrm{~h}$, pretreated with the selective inhibitor of the IGF-IR kinase I-OMe-AG 538 $(20 \mu \mathrm{mol} / \mathrm{l})$ for $10 \mathrm{~min}$, stimulated with PDGF-BB $(10 \mathrm{ng} / \mathrm{ml})$ and $/$ or IGF-I $(100 \mathrm{nmol} / \mathrm{l})$ for $10 \mathrm{~min}$ and immediately subjected to detergent lysis followed by immunoprecipitation (IP) of PDGFR $\beta$. Subsequently, after SDS-PAGE and electroblotting, tyrosine phosphorylation of PDGFR $\beta$ was evaluated by Western blotting (WB) with antiphosphotyrosine antibodies (anti-pY). Equal loading of proteins was ensured by reprobing immunoblots with antibodies used for immunoprecipitation. The sizes of proteins are indicated on the left. The relative densities of bands are expressed as fold increase compared with the level of phosphorylated PDGFR $\beta$ in untreated cultures. Statistically significant differences are indicated: ${ }^{*} P<0.01$ by ANOVA $(n=3$ independent experiments).

\section{Differential Regulation of IGF-IR and PDGFR mRNA Expression by PDGF-BB and IGF-I}

In LMFs, PDGF-BB and IGF-I demonstrated divergent effects on IGF-IR and PDGFR expression. As shown by Northern blot analysis, IGF-I reduced the IGF-IR mRNA expression with maximal effect after $36 \mathrm{~h}$, whereas $\mathrm{GH}$ and insulin had no significant effect (Figure 3a). In turn, Western blot (WB)

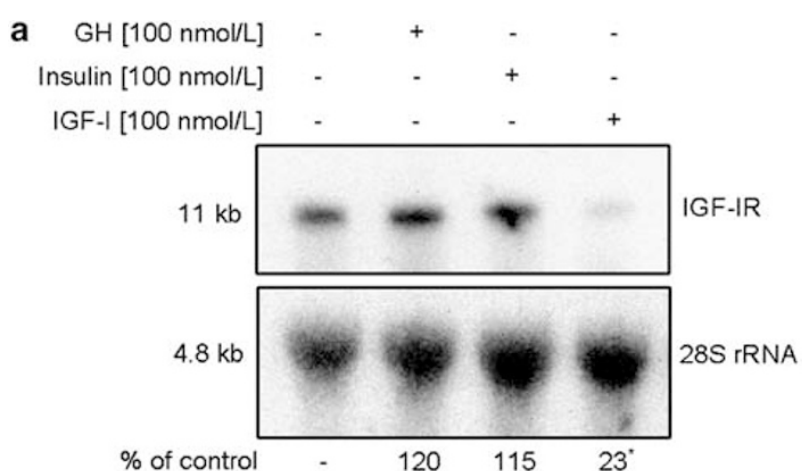

b

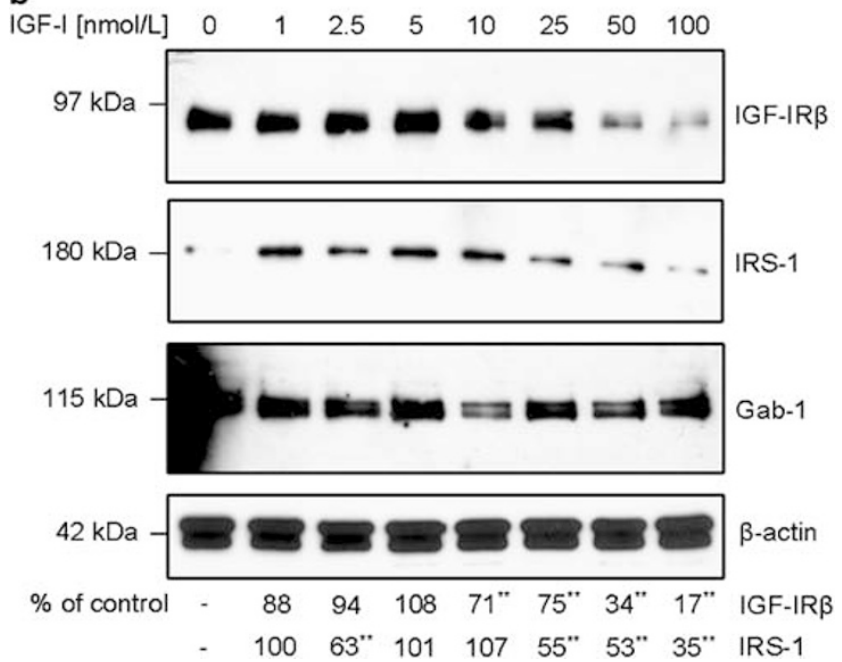

Figure 3 IGF-I-induced downregulation of the IGF-IR in LMFs. (a) Upper panel: total RNA (10 $\mu \mathrm{g})$ isolated from LMFs incubated in the presence or absence of $\mathrm{GH}$, insulin and IGF-I each at concentration of $100 \mathrm{nmol} / \mathrm{l}$ for $36 \mathrm{~h}$ were separated by $1 \%$ agarose gel electrophoresis, blotted and probed for rat IGF-IR. Lower part: equal loading of RNA was demonstrated after stripping and rehybridization of membranes with an oligonucleotide complementary to $28 \mathrm{~S}$ rRNA. The sizes of the hybridization bands (in $\mathrm{kb}$ ) are indicated on the left. The relative densities of bands were expressed as percent increase or decrease of IGF-IR mRNA levels compared with IGF-IR mRNA expression in untreated cultures. Statistically significant differences are indicated: ${ }^{*} P<0.05$ by ANOVA ( $n=3$ independent experiments). (b) LMFs were incubated in serum-reduced medium in the presence of increasing concentrations of IGF-I $(0,1,2.5,5,10,25,50$ and $100 \mathrm{nmol} / \mathrm{l})$ for $36 \mathrm{~h}$. Proteins $(25 \mu \mathrm{g})$ extracted from whole cell lysates were size-fractionated by SDS-PAGE and immunoblotted with anti-IGF-IR $\beta$, anti-IRS-1 and anti-Gab-1 antibodies. Equal loading of proteins was demonstrated by immunoblotting with an antibody directed against $\beta$-actin. The sizes of proteins are indicated on the left. The relative densities of bands are expressed as percent decrease of IGF-IR $\beta$, IRS- 1 and Gab- 1 compared with the respective protein levels in untreated cultures. Statistically significant differences are indicated: ${ }^{*} P<0.05,{ }^{*} P<0.01$ by ANOVA ( $n=3$ independent experiments).

analysis revealed that incubation of LMFs with IGF-I resulted in an inhibition of synthesis of the IGF-IR $\beta$ subunit (Figure 3b). The inhibitory effect of IGF-I on the IGF-IR $\beta$ production was observed only at high concentrations (50 and $100 \mathrm{nmol} / \mathrm{l}$ ). Moreover, IGF-I also decreased the abundance of IRS-1, a 
principal signaling element of the IGF-IR. This effect was specific because the levels of another IRS protein, Gab-1, were not affected by increasing concentrations of IGF-I. In contrast, recombinant PDGF-BB time-dependently increased the IGF-IR mRNA expression showing maximal effect after $24 \mathrm{~h}$ of treatment as demonstrated by Northern blot analysis (Figure 4a). These data were confirmed by WB analysis, which showed that incubation of LMFs with increasing concentrations of PDGF-BB resulted in a dose-dependent increase of the IGF-IR $\beta$ levels (Figure 4b). Furthermore, IGF-I-induced downregulation of the IGF-IR was effectively prevented by addition of recombinant PDGF-BB (Figure 5). In this experiment, PDGF-BB alone did not significantly alter the IGF-IR mRNA expression. The discrepancy between PDGF-mediated upregulation of the IGF-IR mRNA expression as shown in
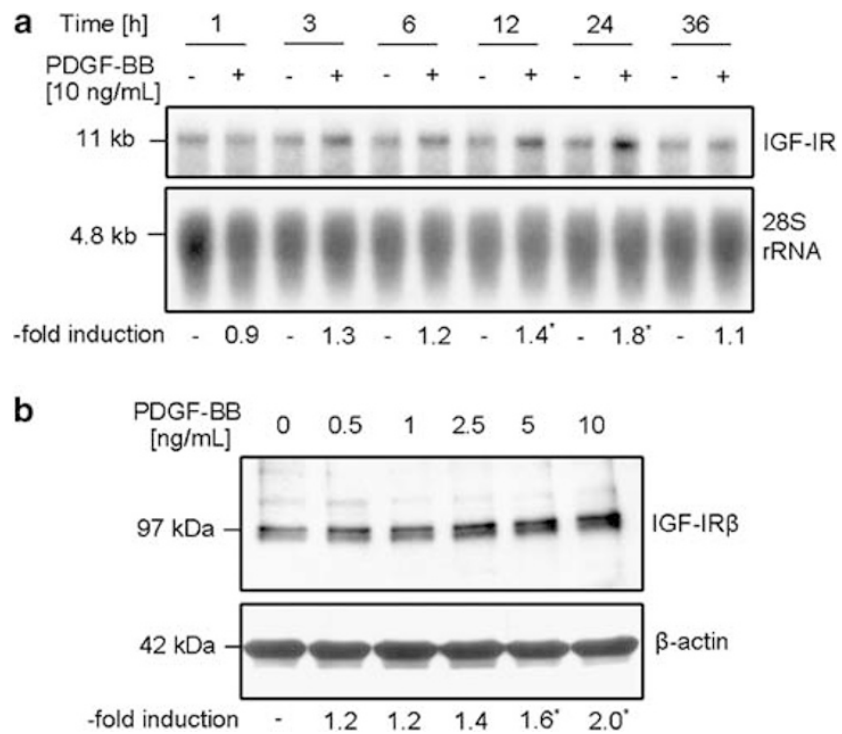

Figure 4 PDGF-induced upregulation of the IGF-IR expression in LMFs. (a) Upper part: $10 \mu \mathrm{g}$ of total RNA isolated from LMFs treated with PDGF-BB $(10 \mathrm{ng} / \mathrm{ml})$ for $1,3,6,12,24$ and $36 \mathrm{~h}$ were separated by $1 \%$ agarose gel electrophoresis, blotted and hybridized with a radiolabeled cDNA specific for rat IGF-IR. Lower part: equal loading of RNA was demonstrated after stripping and rehybridization of membranes with an oligonucleotide complementary to $28 \mathrm{~S}$ rRNA. The sizes of the hybridization bands (in kb) are indicated on the left. The relative densities of bands are expressed as percent increase of IGF-IR mRNA levels compared with IGF-IR mRNA expression in untreated cultures. Statistically significant differences are given: ${ }^{*} P<0.05$ by ANOVA ( $n=3$ independent experiments). (b) LMFs were incubated in serum-reduced medium in the presence of increasing concentrations of PDGF-BB $(0,0.5,1,2.5,5$ and $10 \mathrm{ng} / \mathrm{ml})$ for $24 \mathrm{~h}$. Proteins $(25 \mu \mathrm{g})$ extracted from whole cell lysates were sizefractionated by SDS-PAGE and immunoblotted with anti-IGF-IR $\beta$ antibody. Equal loading of proteins was demonstrated by immunoblotting with an antibody directed against $\beta$-actin. The sizes of proteins are indicated on the left. The relative densities of bands are expressed as fold increase of IGF-IR $\beta$ compared with the respective protein levels in untreated cultures. Statistically significant differences are indicated: ${ }^{*} P<0.05$ by ANOVA $(n=3$ independent experiments).
Figure 4 vs unaffected expression as shown in Figure 5 is due to different modes of treatment in both experiments. In experiments depicted in Figure $4 \mathrm{~b}, \mathrm{LMFs}$ were incubated with PDGF-BB for $24 \mathrm{~h}$, whereas the duration of treatment in experiments shown in Figure 5 was $36 \mathrm{~h}$. This is an important point with regard to the time course of the IGF-IR mRNA expression after PDGF stimulation where maximal effects observed at $24 \mathrm{~h}$ returned to their basal levels after $36 \mathrm{~h}$.

Remarkably, IGF-I inhibited mRNA expression of PDGFR $\alpha$, which was also partially restored by addition of PDGF-BB (Figure 5). However, IGF-I had no effect on the PDGFR $\beta$ mRNA expression (Figure 5). Interestingly, in contrast to the IGF-IR, which undergoes ligand-induced downregulation, gene expression of both PDGFR subunits was not inhibited by their cognate ligand (Figure 5).

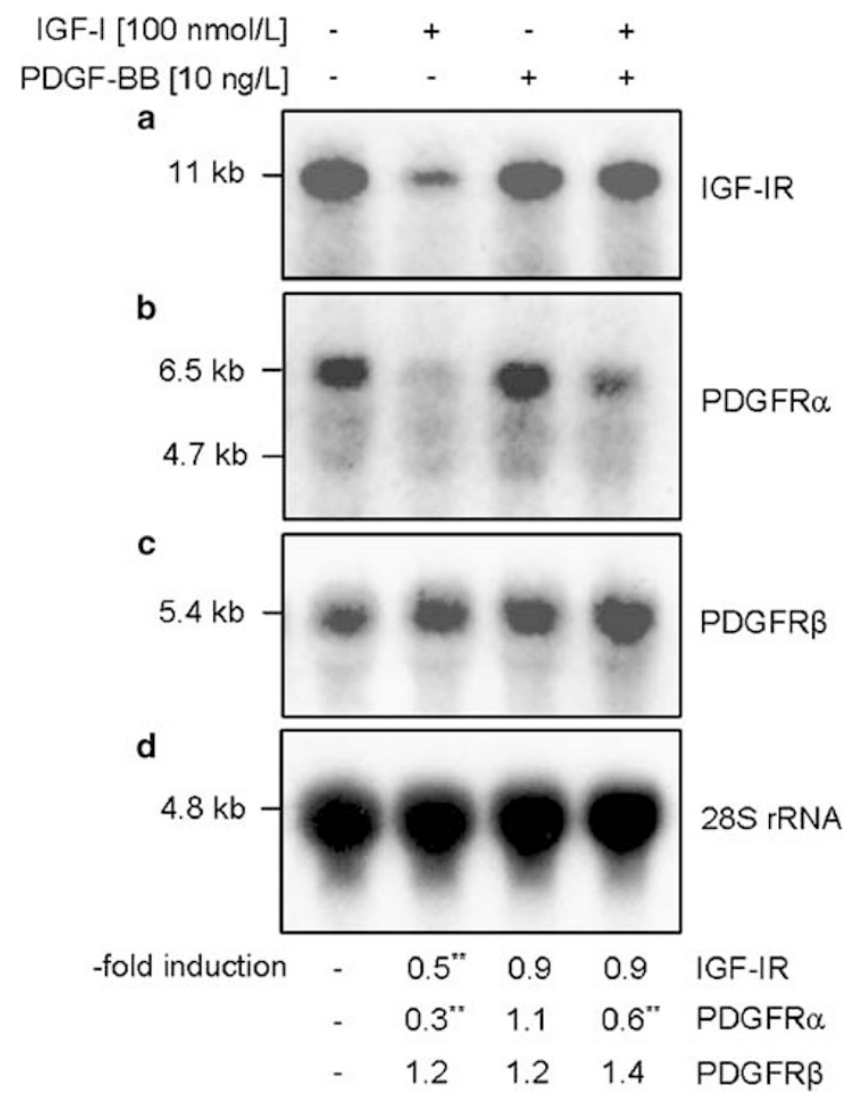

Figure 5 Effect of PDGF on IGF-IR and PDGFR mRNA expression in LMFs. (a-c) $10 \mu \mathrm{g}$ of total RNA isolated from LMFs treated with IGF-I $(100 \mathrm{nmol} / \mathrm{l})$ and/or PDGF-BB $(10 \mathrm{ng} / \mathrm{ml})$ for $36 \mathrm{~h}$ were separated by $1 \%$ agarose gel electrophoresis, blotted and probed for rat IGF-IR (a), PDGFR $\alpha$ (b) and PDGFR $\beta$ (c), respectively. (d) Equal loading of RNA was demonstrated after stripping and rehybridization of membranes with an oligonucleotide complementary to $28 \mathrm{~S}$ rRNA. The sizes of the hybridization bands (in $\mathrm{kb}$ ) are indicated on the left. The relative densities of bands are expressed as fold increase or decrease in mRNA levels of IGF-IR or PDGFR, respectively, compared with the respective mRNA levels in untreated cultures. Statistically significant differences are indicated: ${ }^{*} P<0.01$ by ANOVA $(n=4$ independent experiments). 
IGF-I- and PDGF-Induced Tyrosine Phosphorylation of IGF-IR, PDGFR, IRS-1 and PLC $\gamma_{1}$

Since transphosphorylation of heterologous receptors has been known to occur, we next wished to investigate whether the PDGFR and IGF-IR can directly transactivate each other. For this purpose, the IGF-IR $\beta$, the PDGFR $\beta$ and their principal signaling elements, IRS- 1 and PLC $\gamma_{1}$, respectively, were precipitated from lysed cells treated with IGF-I or PDGF-BB for $10 \mathrm{~min}$ under serum-free conditions. The activated status of the precipitated proteins was visualized by immunoblotting with an antiphosphotyrosine antibody. Activation of the PDGFR $\alpha$ was demonstrated by WB analysis with phospho-specific antibodies against PDGFR $\alpha$. Treatment with IGF-I resulted in the tyrosine phosphorylation of the IGFIR $\beta$ subunit and IRS-1 (Figure 6). PDGF-BB induced the tyrosine phosphorylation of both PDGFR subunits and PLC $\gamma_{1}$. Transactivation of IGF-IR by PDGFR and PDGFR by IGF-IR was not observed. In turn, transphosphorylation of IRS-1 by PDGFR and PLC $\gamma_{1}$ by IGF-IR was excluded as well. When IGF-I and PDGF-BB were applied together to cultured cells, there was no additive tyrosine phosphorylation of the receptors and their major signaling intermediates. Conversely, IGF-I inhibited the phosphorylation of the PDGFR, in particular of its $\alpha$ subunit, and the IGF-I-induced tyrosine phosphorylation of IRS-1 was attenuated by addition of PDGF-BB.

\section{Effect of MAPK Pathway Inhibitors on IGF-I- and PDGF-Stimulated DNA Synthesis}

The mechanism by which the IGF-IR cooperates with the PDGFR during mitogenic response is not understood. It has been suggested that the IGF-IR is probably more effective in inducing cell signaling through the MAPK pathway. To test this hypothesis, the effect of pharmacological inhibitors of MAPK

Figure 6 IGF-I- and PDGF-induced tyrosine phosphorylation of the IGF-IR $\beta$ subunit and IRS-1 (a) as well as PDGFR $\alpha$ and $\beta$ subunits and PLC $\gamma_{1}$ (b) in LMFs. Serum starved cells were stimulated with IGF-I ( $100 \mathrm{nmol} / \mathrm{l})$ and/or PDGF-BB $(10 \mathrm{ng} / \mathrm{ml})$ for $10 \mathrm{~min}$ and immediately subjected to detergent lysis followed by immunoprecipitation (IP) of IGF-IR $\beta$, IRS-1, PDGFR $\beta$, and PLC $\gamma_{1}$. Subsequently, after SDS-PAGE and electroblotting, tyrosine phosphorylation of the precipitated proteins was evaluated by WB analysis with antiphosphotyrosine antibodies (anti-pY). Equal loading of proteins was ensured by reprobing immunoblots with antibodies used for immunoprecipitation. For PDGFR $\alpha, 50 \mu \mathrm{g}$ of proteins extracted from cell lysates were size-fractionated by SDS-PAGE and immunoblotted with antibodies raised against the phosphorylated form of PDGFR $\alpha$. Equal loading of proteins was demonstrated by immunoblotting with an antibody directed against the nonphosphorylated form of the PDGFR $\alpha$. The sizes of proteins are indicated on the left. The relative densities of bands are expressed as fold increase of phosphorylated forms of IGF-IR $\beta$, IRS- 1 , PDGFR $\beta$, PDGFR $\alpha$ and PLC $\gamma_{1}$, respectively, compared with the respective phosphoprotein levels in untreated cultures. Statistically significant differences are indicated: ${ }^{*} P<0.01$ by ANOVA ( $n=3$ independent experiments). pathway components on PDGF- and IGF-I-induced DNA synthesis has been investigated. For this purpose, LMFs at day 2 of culture were stimulated with IGF-I $(10 \mathrm{nmol} / \mathrm{l})$ or PDGF-BB $(10 \mathrm{ng} / \mathrm{ml})$ in the presence or absence of the respective pharmacological inhibitor (10 and $20 \mu \mathrm{mol} / \mathrm{l}$ ) for $24 \mathrm{~h}$. As demonstrated by BrdU incorporation assay, an inhibition of MEK by PD98059, p38 kinase by

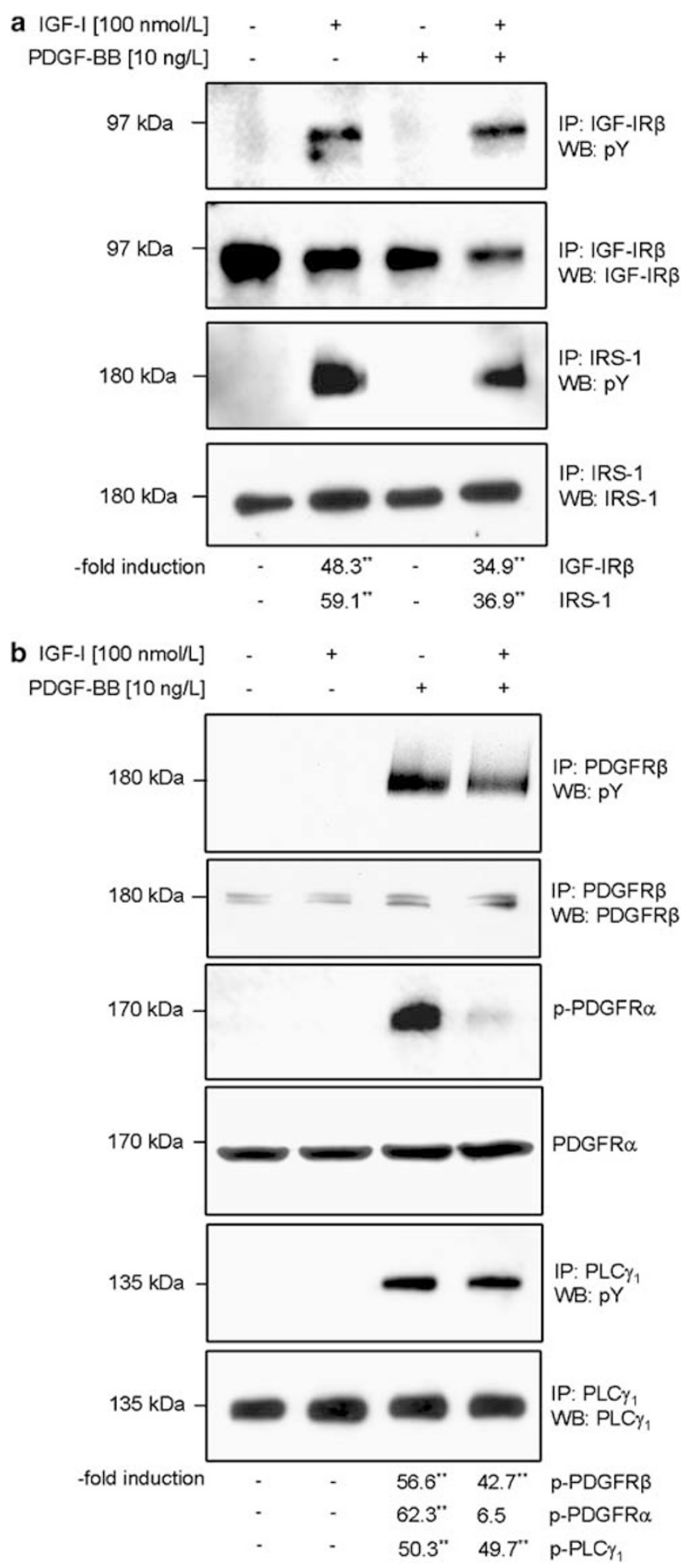


a

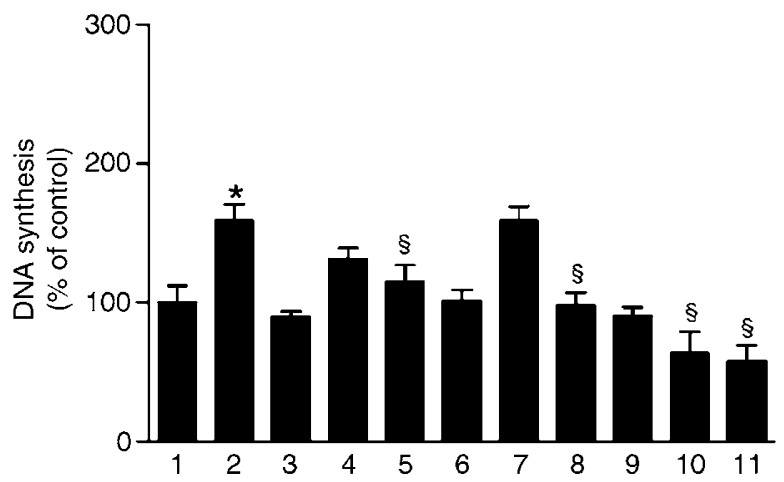

\begin{tabular}{|c|c|c|c|c|c|c|c|c|c|c|c|}
\hline IGF-I [nmo/L] & - & 10 & - & 10 & 10 & - & 10 & 10 & - & 10 & 10 \\
\hline PD98059 $[\mu \mathrm{mol} / \mathrm{L}]$ & - & - & 20 & 10 & 20 & - & - & - & - & - & - \\
\hline SB203580 $[\mu \mathrm{mol} / \mathrm{L}]$ & - & - & - & - & - & 20 & 10 & 20 & - & - & - \\
\hline SP600125 $[\mu \mathrm{mol} / \mathrm{L}]$ & - & - & - & - & - & - & - & - & 20 & 10 & 20 \\
\hline
\end{tabular}

b

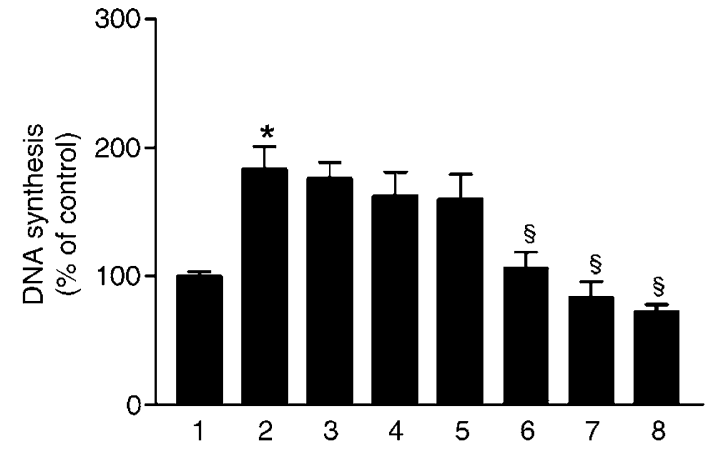

\begin{tabular}{|c|c|c|c|c|c|c|c|c|}
\hline PDGF-BB [ng/mL] & - & 10 & 10 & 10 & 10 & 10 & 10 & 10 \\
\hline PD98059 [ $\mu \mathrm{mol} / \mathrm{L}]$ & - & & 10 & 20 & - & - & - & - \\
\hline SB203580 [ $\mu \mathrm{mol} / \mathrm{L}]$ & - & - & - & - & 10 & 20 & - & \\
\hline SP600125 [ $\mu \mathrm{mol} / \mathrm{L}]$ & - & - & - & - & - & - & 10 & 20 \\
\hline
\end{tabular}

Figure 7 Effect of MAPK pathway inhibitors on IGF-I- and PDGFstimulated DNA synthesis in LMFs. After starvation for $1 \mathrm{~h}$, cells were treated for $24 \mathrm{~h}$ with IGF-I (10 nmol/l) (a) or PDGF-BB (10 ng/ $\mathrm{ml}$ ) (b) in the presence or absence of the MEK inhibitor PD98059, the p38 kinase inhibitor SB203580 and the JNK inhibitor SP600125 at concentrations of 10 and $20 \mu \mathrm{mol} / \mathrm{l}$. Control cultures were maintained in serum-reduced DMEM for $24 \mathrm{~h}$. All cells received the same amount of DMSO. DNA synthesis was evaluated by BrdU incorporation assay. Results are expressed as the percentage of incorporation \pm s.e.m. relative to the control ( $n=3$ independent experiments in quadruplicate). Statistically significant difference: $P<0.05$ vs untreated control cultures $\left({ }^{*}\right)$ or growth factor (§) treated cultures.

SB203580 and JNK by SP600125 effectively blocked IGF-I-induced mitogenic activity (Figure 7). Likewise, mitogenic activity of PDGF-BB was abrogated when JNK and p38 kinase were inactivated. In contrast to IGF-I, however, the rate of PDGF-induced DNA synthesis was unaffected when activation of ERK1 and ERK2 was prevented.

\section{Effect of IGF-I and PDGF on MAPK Activation}

To investigate whether IGF-I is more effective than PDGF in activating terminal MAP kinases, proteins

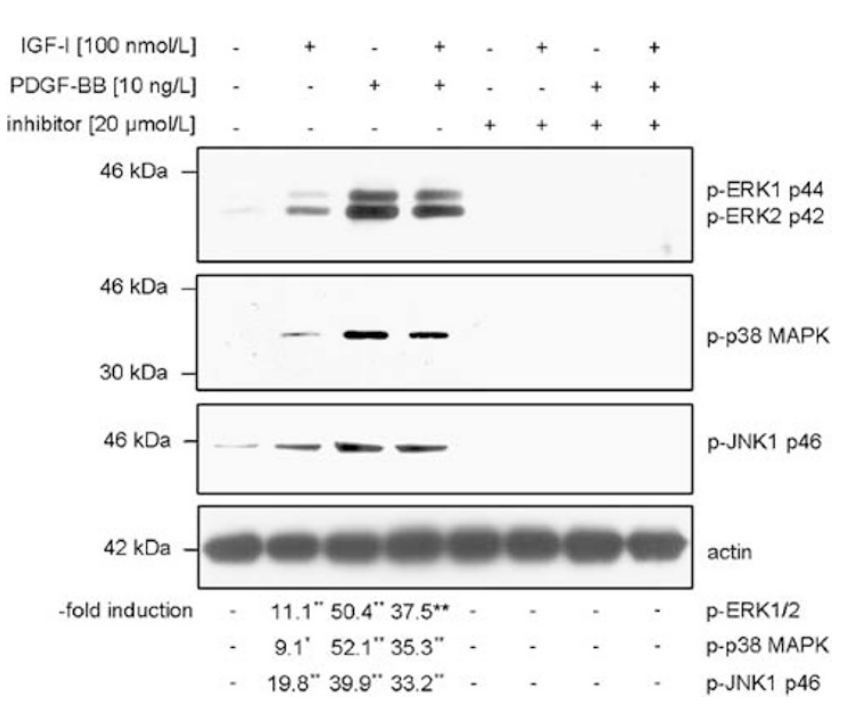

Figure 8 Effect of IGF-I and PDGF-BB on MAPK activation in LMFs. Serum starved cells were stimulated with IGF-I $(100 \mathrm{nmol} /$ l) and/or PDGF-BB $(10 \mathrm{ng} / \mathrm{ml})$ for $10 \mathrm{~min}$ in the presence or absence of the MEK inhibitor PD98059 (anti-ERK1/2 WB), the p38 kinase inhibitor SB203580 (anti-p38 MAPK WB) or the JNK inhibitor SP600125 (anti-JNK1 WB), respectively, at the concentration of $20 \mu \mathrm{mol} / \mathrm{l}$ and immediately subjected to detergent lysis. Proteins $(50 \mu \mathrm{g})$ extracted from whole cell lysates were sizefractionated by SDS-PAGE and immunoblotted with antibodies raised against dually phosphorylated forms of ERK1/2, p38 MAPK and JNK1. Equal loading of proteins was demonstrated by immunoblotting with an antibody directed against $\beta$-actin. The positions of the molecular weight standards are indicated on the left. The relative densities of bands are expressed as fold increase of phosphorylated forms of ERK1/2, p38 MAPK and JNK1, respectively, compared with the respective phosphoprotein levels in untreated cultures. Statistically significant differences are indicated: ${ }^{*} P<0.01,{ }^{*} P<0.001$ by ANOVA $(n=3$ independent experiments).

extracted from LMFs treated with IGF-I and PDGF$\mathrm{BB}$ for $10 \mathrm{~min}$ under serum-free conditions were further subjected to WB analysis with antibodies raised against dually phosphorylated forms of ERK1/2, p38 kinase and JNK. These experiments revealed that PDGF-BB was definitely more effective in activating MAP kinases than IGF-I (Figure 8). Moreover, when both growth factors were simultaneously added to cells, IGF-I did not show an additive effect on MAP kinases activation. Cells simultaneously treated with IGF-I and PDGF-BB and cells treated with PDGF-BB alone had the same level of MAPK phosphorylation. IGF-I- and PDGF-induced phosphorylation of ERK1/2, p38 kinase and JNK were completely inhibited in the presence of their specific pharmacological inhibitors.

\section{Effect of PLC Inhibitor and Activator on DNA Synthesis}

As it has previously been shown that phospholipase $\mathrm{C}$ is required for amplification of cell signaling through the MAPK pathway, the role of PLC in PDGF- and IGF-I-induced mitogenesis in rat LMFs 
was investigated. Serum starved LMFs at day 2 of culture were treated with either IGF-I $(10 \mathrm{nmol} / \mathrm{l})$ or PDGF-BB $(10 \mathrm{ng} / \mathrm{ml})$ in the presence or absence of the specific PLC inhibitor U73122 (2.5 and $5 \mu \mathrm{mol} / \mathrm{l}$ ) for $24 \mathrm{~h}$. In parallel, cells were also treated with the specific PLC activator m-3M3FBS $(1 \mathrm{nmol} / \mathrm{l})$. As demonstrated by BrdU incorporation assay (Figure 9a), DNA synthesis of LMFs induced by both PDGF$\mathrm{BB}$ and IGF-I was severely blunted in the presence of

a

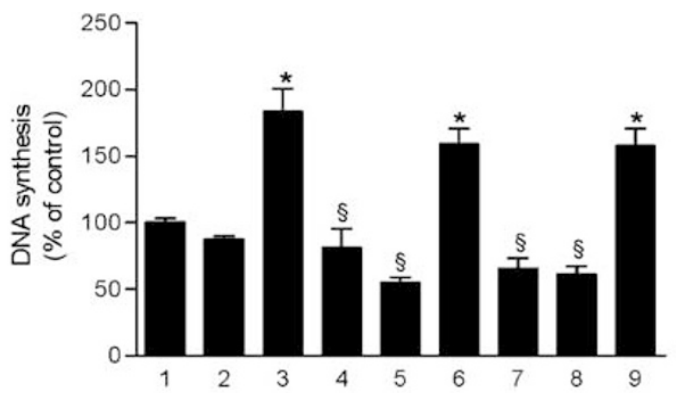

\begin{tabular}{|l|c|c|c|c|c|c|c|c|c|}
\hline PDGF-BB $[\mathrm{ng} / \mathrm{mL}]$ & - & - & 10 & 10 & 10 & - & - & - & - \\
\hline IGF-I [nmo//L] & - & - & - & - & - & 10 & 10 & 10 & - \\
\hline $\mathrm{U} 73122[\mu \mathrm{mol} / \mathrm{L}]$ & - & 5 & - & 2.5 & 5 & - & 2.5 & 5 & - \\
\hline $\mathrm{m}-3 \mathrm{M} 3 \mathrm{FBS}[\mathrm{nmol} / \mathrm{L}]$ & - & - & - & - & - & - & - & - & 1 \\
\hline
\end{tabular}

b

$\begin{array}{lllllll}\text { IGF-I }[100 \mathrm{nmol} / \mathrm{L}] & - & + & - & + & \cdot \\ \text { PDGF-BB }[10 \mathrm{ng} / \mathrm{L}] & - & - & + & + & +\end{array}$
I.OMe-AG $538[20 \mu \mathrm{mol} / \mathrm{L}]$

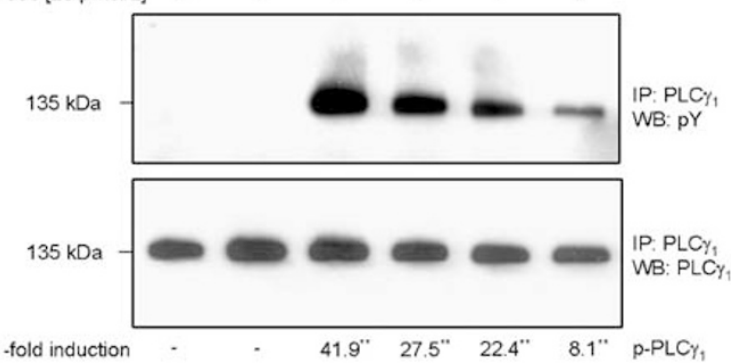

Figure 9 (a) Effect of phospholipase C (PLC) inhibitor and activator on DNA synthesis in LMFs. After starvation for $1 \mathrm{~h}$, cells were treated for $24 \mathrm{~h}$ with IGF-I $(10 \mathrm{nmol} / \mathrm{l})$ or PDGF-BB $(10 \mathrm{ng} / \mathrm{ml})$ in the presence or absence of the specific PLC inhibitor U73122 (2.5 and $5 \mu \mathrm{mol} / 1)$. Alternatively, cells were also treated with the specific PLC activator m-3M3FBS ( $1 \mathrm{nmol} / \mathrm{l})$. Control cultures were maintained in serum-reduced DMEM for $24 \mathrm{~h}$. All cells received the same amount of DMSO. DNA synthesis was evaluated by BrdU incorporation assay. Results are expressed as the percentage of incorporation \pm s.e.m. relative to the control ( $n=3$ independent experiments in quadruplicate). Statistically significant difference: $P<0.05$ vs untreated control cultures $\left({ }^{*}\right)$ or growth factor (§) treated cultures. (b) Effect of IGF-IR blockade on tyrosine phosphorylation of PLC $\gamma_{1}$ in LMFs. Subconfluent cultures of LMFs were maintained in serum-free DMEM for $1 \mathrm{~h}$, pretreated with the selective inhibitor of the IGF-IR kinase I-OMeAG $538(20 \mu \mathrm{mol} / \mathrm{l})$ for $10 \mathrm{~min}$ and stimulated with PDGF-BB $(10 \mathrm{ng} / \mathrm{ml})$ and/or IGF-I $(100 \mathrm{nmol} / \mathrm{l})$ for $10 \mathrm{~min}$. After treatment, cells were immediately subjected to detergent lysis followed by immunoprecipitation (IP) of PLC $\gamma_{1}$, SDS-PAGE and electroblotting. Tyrosine phosphorylation of PLC $\gamma_{1}$ was evaluated by WB with antiphosphotyrosine antibodies (anti-pY). Equal loading of protein was ensured by reprobing immunoblots with anti-PLC $\gamma_{1}$ antibody. The relative densities of bands are expressed as fold increase of phosphorylated PLC $\gamma_{1}$ compared with the phosphoprotein levels in untreated cultures. Statistically significant differences are indicated: ${ }^{*} P<0.001$ by ANOVA $(n=3$ independent experiments).
U73122. In contrast, the PLC activator m-3M3FBS did mimic the mitogenic effect induced by the growth factors.

\section{Effect of IGF-IR Blockade on Tyrosine Phosphorylation of PLC $\gamma_{1}$}

It has been demonstrated in previous experiments that PLC $\gamma_{1}$, which apparently plays an essential role in proliferation of LMFs, was phosphorylated only in response to PDGF-BB but not to IGF-I. To investigate whether a functional IGF-IR is required for full activation of PLC $\gamma_{1}$, subconfluent cultures of LMFs were maintained in serum-free medium for $1 \mathrm{~h}$, pretreated with the selective inhibitor of the IGF-IR kinase I-OMe-AG $538(20 \mu \mathrm{mol} / \mathrm{l})$ for $10 \mathrm{~min}$, and stimulated with PDGF-BB $(10 \mathrm{ng} / \mathrm{ml})$ and/or IGF-I $(100 \mathrm{nmol} / \mathrm{l})$ for $10 \mathrm{~min}$. Consequently, PLC $\gamma_{1}$ was imunoprecipitated from whole cell lysates, subjected to SDS-PAGE, and finally the phosphorylated form of PLC $\gamma_{1}$ was visualized by immunoblotting with an antiphosphotyrosine antibody. In agreement with previous data, treatment of cells with IGF-I alone did not lead to the tyrosine phosphorylation of $\mathrm{PLC} \gamma_{1}$ (Figure 9b). PDGF-BB effectively induced phosphorylation of PLC $\gamma_{1}$. However, blockade of the IGF-IR by the selective inhibitor was accompanied by a reduced phosphorylation of PLC $\gamma_{1}$ in cells treated with PDGF-BB. Interestingly, high concentrations of IGF-I also inhibited the phosphorylation of PLC $\gamma_{1}$. Moreover, this inhibitory effect of IGF-I was additive to that of I-OMe-AG 538. The IGF-I-dependent inhibition of PLC $\gamma_{1}$ phosphorylation in the latter case could not be mediated by the IGF-IR, which was specifically blocked by its selective inhibitor. However, it is well known that the IGF-IR and the insulin receptor act as bivalent receptors, which are capable of binding both insulin and IGF-I. ${ }^{9}$ Therefore, it is very likely that IGF-I could also act through the insulin receptor in the aforementioned case. Of note, LMFs are known to express significant amounts of the insulin receptor on their surface (own unpublished observation).

\section{Effect of IGF-I and PDGF on PI3K Pathway}

The PI3K pathway represents another convergent point in the cell, where interaction between IGFand PDGF-induced signaling might occur. As in LMFs PDGF-BB appears to be considerably more effective in activating MAPK pathway than IGF-I, it has also been suggested that IGF-I could probably be more efficient in transducing cell signal through the PI3K pathway. To address this question, DNA synthesis of LMFs stimulated with IGF-I $(10 \mathrm{nmol} /$ l) and/or PDGF-BB $(10 \mathrm{ng} / \mathrm{ml})$ in the presence or absence of the PI3K inhibitor LY294002 (5, 10, $20 \mu \mathrm{mol} / \mathrm{l}$ ) for $24 \mathrm{~h}$ was analyzed by BrdU incorporation assay (Figure 10a). This experiment demon- 
a

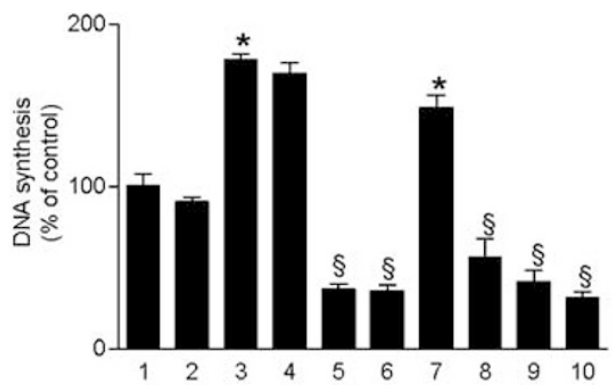

\begin{tabular}{|c|c|c|c|c|c|c|c|c|c|c|}
\hline PDGF-BB [ng/mL] & - & . & 10 & 10 & 10 & 10 & - & - & - & $\cdot$ \\
\hline IGF-1 [nmol/L] & 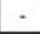 & - & ${ }^{-}$ & - & - & - & 10 & 10 & 10 & 10 \\
\hline LY294002 [ [umo/ll] & - & 20 & - & 5 & 10 & 20 & - & 5 & 10 & 20 \\
\hline
\end{tabular}

b

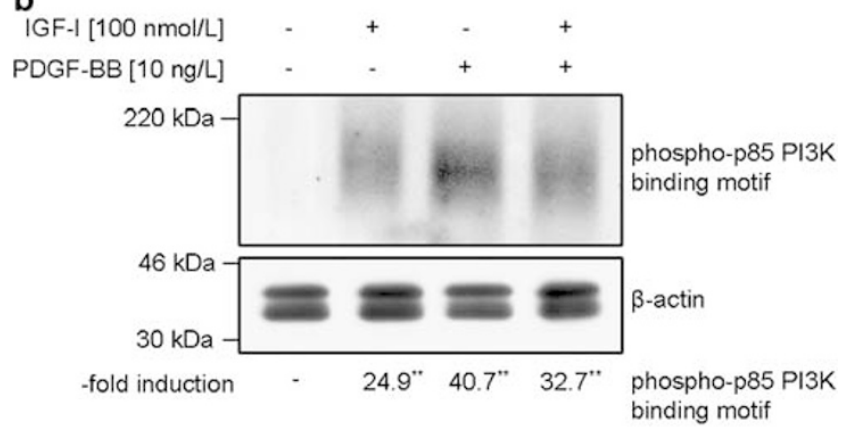

C

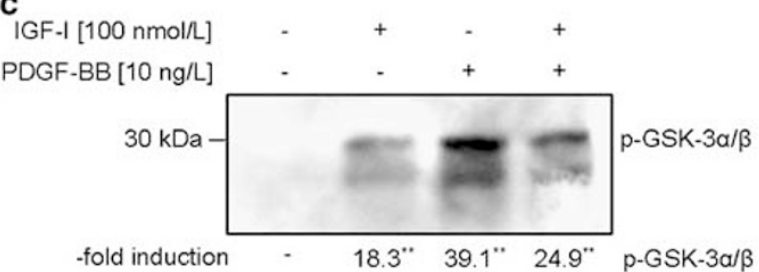

Figure 10 Effect of IGF-I and PDGF on activation of the PI3 kinase (PI3K) pathway. (a) After starvation for $1 \mathrm{~h}$, cells were treated for $24 \mathrm{~h}$ with IGF-I $(10 \mathrm{nmol} / \mathrm{l})$ and/or PDGF-BB $(10 \mathrm{ng} / \mathrm{ml})$ in the presence or absence of the PI3K inhibitor LY294002 at concentrations of 5, 10 and $20 \mu \mathrm{mol} / \mathrm{l}$. Control cultures were maintained in serum-reduced DMEM for $24 \mathrm{~h}$. All cells received the same amount of DMSO. DNA synthesis was determined by BrdU incorporation assay. Results are expressed as the percentage of incorporation \pm s.e.m. relative to the control $(n=3$ independent experiments in quadruplicate). Statistically significant difference: $P<0.05$ vs. untreated control cultures $\left({ }^{*}\right)$ or growth factor $(\S)$ treated cultures. $(n=4)(\mathbf{b}, \mathbf{c})$ Serum starved cells were stimulated with IGF-I (100 nmol/l) and/or PDGF-BB $(10 \mathrm{ng} / \mathrm{ml})$ for $10 \mathrm{~min}$ and immediately subjected to detergent lysis. (b) Proteins $(50 \mu \mathrm{g})$ extracted from whole cell lysates were size-fractionated by SDSPAGE and immunoblotted with antibodies raised against the phospho-(Tyr) p85 PI3K binding motif. Equal loading of proteins was demonstrated by immunoblotting with an antibody directed against $\beta$-actin. (c) Akt was immunoprecipiated from $200 \mu \mathrm{g}$ of proteins extracted from cell lysates by an immobilized Akt monoclonal antibody followed by an in vitro kinase assay using GSK-3 fusion protein as a substrate. Phosphorylation of GSK-3 was measured by WB using a phospho-GSK- $3 \alpha / \beta$ antibody. The relative densities of bands are expressed as fold increase of the amount of p85 PI3K binding motifs or phosphorylated form of GSK-3 protein, respectively, compared with their levels in untreated cultures. Statistically significant differences are indicated: ${ }^{* *} P<0.001$ by ANOVA ( $n=3$ independent experiments).

strated a strong dose-dependent inhibition of IGF-Iinduced mitogenic activity by LY294002. In contrast to IGF-I, the rate of PDGF-induced DNA synthesis was only inhibited when LY294002 was added at concentrations of 10 and $20 \mu \mathrm{mol} / \mathrm{l}$, respectively, whereas LY294002 at $5 \mu \mathrm{mol} / \mathrm{l}$ did not significantly change PDGF-induced BrdU incorporation (Figure 10a). Further we studied the effect of IGF-I and PDGF on activation of PI3K. For this purpose proteins were extracted from LMFs treated with IGF-I and PDGF-BB for $10 \mathrm{~min}$ under serum-free conditions and analyzed by WB analysis using antibodies against the phospho-(Tyr) p85 PI3K binding motif (Figure 10b). This antibody preferentially recognizes a wide range of peptides and proteins containing phosphotyrosine at the consensus YXXM motif, which is capable of binding to regulatory p85 subunit of PI3K. These experiments demonstrated p85 PI3K binding proteins of approximately $180 \mathrm{kDa}$ in cultures of LMFs treated with PDGF-BB and IGF-I, respectively. In PDGF-BBtreated cell cultures the amount of phosphorylated p85 binding motifs was considerably higher compared with IGF-I-treated cultures. Both growth factors added simultaneously to LMFs did not increase the amount of phosphorylated p85 PI3K binding motifs. The impact of IGF-I and/or PDGF-BB was also studied on Akt kinase, a downstream target of the PI3K pathway. The results of Akt kinase assay demonstrate that PDGF-BB was more efficient in stimulating Akt kinase activity than IGF-I as estimated by the presence of a phosphorylated GSK-3 fusion protein. Moreover, in line with the data described above, IGF-I and PDGF-BB given together had no additive effect.

\section{Discussion}

In liver cirrhosis hepatic IGF-I expression and serum IGF-I levels are reduced and associated with numerous complications. ${ }^{24-28}$ PDGF, a growth factor that shares many common features with IGF-I, reveals a totally different expression dynamics in liver cirrhosis. Healthy liver tissue is lacking a significant expression of PDGFs and their receptors, and healthy individuals have low serum PDGF levels. In contrast, in liver cirrhosis, hepatic expression and circulating levels of PDGFs are considerably higher and positively correlate with the severity of disease. ${ }^{29,30}$ Despite the different temporal patterns during liver fibrogenesis, both IGF-I and PDGF have been demonstrated as important growth-promoting factors for LMFs in vitro. Therefore, in the current work we aimed to elucidate a pathophysiological link between IGF-I and PDGF-dependent signal transduction in rat LMFs.

Herein, we demonstrate that within rat liver only cells with fibrogenic potential, that is LMFs and HSCs, expressed both subunits of the PDGFR. Furthermore, the PDGFR expression was substantially upregulated during cultivation of LMFs and HSCs in vitro, and this upregulation positively correlated with the mitogenic response to PDGF. 
Further experiments have demonstrated that in LMFs the IGF-IR was required for the mitogenic activity of the PDGFR since simultaneous incubation of cells with PDGF-BB and I-OMe-AG 538, a selective inhibitor of the IGF-IR kinase, or functionblocking anti-IGF-IR $\beta$ antibodies reduced PDGFdependent mitogenic response. Intriguingly, similar data were obtained in mouse embryo fibroblasts with a targeted disruption of the IGF-IR gene which were unable to proliferate after addition of PDGF. ${ }^{14}$ In turn, overexpression of the PDGFR $\beta$ in the IGF-IR negative cells did not restore the capability of cells to proliferate in response to PDGF. Only reintroduction of the IGF-IR restored PDGF-mediated cell proliferation. ${ }^{14}$ The molecular mechanisms that account for the necessity of the IGF-IR for PDGFmediated mitogenesis remain poorly understood, though it has been demonstrated that PDGF increased the promoter activity of the IGF-IR gene and stimulated expression and/or secretion of endogenous IGF-I in certain cell types. ${ }^{13,31-33}$ In LMFs, PDGF$\mathrm{BB}$ affected neither gene expression nor secretion of endogenous IGF-I (data not shown). However, PDGF-BB increased gene expression and synthesis of the IGF-IR in a concentration- and time-dependent manner, and this effect was opposite to that of IGF-I. The ability of IGF-I to induce a downregulation of the IGF-IR is well known and is considered as a negative feedback mechanism in nonmalignant cells. ${ }^{34-38}$ In line with these reports, the data of the current work demonstrate that in LMFs high concentrations of IGF-I effectively inhibited the IGF-IR expression at both mRNA and protein level. Furthermore, expression of IRS-1, a principal signaling element of the IGF-IR, was also dosedependently inhibited by IGF-I, most likely via induction of the ubiquitin-mediated proteasome degradation of IRS-1. ${ }^{39}$ In contrast, IGF-I-induced downregulation of the IGF-IR was effectively prevented by addition of PDGF-BB. IGF-I also substantially inhibited gene expression of the PDGFR $\alpha$, though the PDGFR $\beta$ mRNA levels were unaffected by IGF-I that apparently is associated with different functions of both PDGFR subunits in LMFs. ${ }^{40,41}$ It is also noteworthy that in contrast to the IGF-IR, the expression of both PDGFR subunits in LMFs was not inhibited by their cognate ligand that might be an important mechanism underlying the perpetuation of fibroproliferative response in the liver in vivo.

One of the questions addressed in the current work was whether the PDGFR and IGF-IR can directly transactivate each other or crosstalk at the level of their principal signaling intermediates. In LMFs, the two receptors did not interact physically with each other (data not shown). Transactivation of neither IGF-IR by PDGFR nor PDGFR by IGF-IR was observed, and transphosphorylation of IRS-1 by PDGFR and PLC $\gamma_{1}$ by IGF-IR has been ruled out as well. Addition of IGF-I to cultures of LMFs along with PDGF-BB did not result in an additive tyrosine phosphorylation of the PDGFR and PLC $\gamma_{1}$. Contra- riwise, IGF-I inhibited the phosphorylation of the PDGFR, in particular of its $\alpha$ subunit. Therefore, it can be speculated that the mechanism that represses fibrogenesis in healthy liver despite high hepatic IGF-I levels is based, at least in part, on IGF-Idependent downregulation of the IGF-IR, IRS-1 and PDGFR $\alpha$ as well as inhibition of the PDGFR phosphorylation.

Nevertheless, the question by which mechanism the IGF-IR cooperates with the PDGFR during mitogenic response remains open. It has been proposed that the IGF-IR probably is more effective in cell signaling through the MAPK cascade. However, the data of the present study demonstrate that PDGF-BB effectively induced phosphorylation of all terminal MAP kinases in LMFs in contrast to IGF-I, which showed only weak effects. Addition of IGF-I to cells treated with PDGF-BB was not accompanied by an additive activation of MAP kinases. Inactivation of JNK and p38 kinase resulted in abrogation of mitogenic effects induced by PDGF-BB. However, the rate of PDGF-induced DNA synthesis was unaffected when phosphorylation of ERK1 and ERK2 was prevented by blockade of MEK, although PDGF-BB induced pronounced activation of ERK1 and ERK2. Abundant evidence demonstrates that MAP kinases have overlapping substrate specificities. It is well known that some key transcription factors involved in cell division and proliferation, for example, Elk-1 and ATF-2, can be equally activated by ERK1/2, JNK and p38 kinase. ${ }^{42,43}$ Therefore, it is likely that during PDGF-induced mitogenesis ERK blockade is compensated by JNK and p38 kinase, which are markedly phosphorylated in response to PDGF and very weakly in response to IGF-I. But, again, that implies that PDGF-induced MAPK signaling is much more effective than that induced by IGF-I.

Alternatively, it has also been suggested that the IGF-IR could be more efficient in transducing cell signaling through the PI3K pathway. However, our data demonstrate that in LMFs PDGF-BB was also a stronger activator of the PI3K pathway than IGF-I as estimated by the amount of phosphorylated p85 PI3K binding motifs and Akt kinase activity. Intriguingly, in LMFs high concentrations of IGF-I tended to attenuate activation of the PI3K pathway, although the PDGF-induced phosphorylation of MAP kinases remained unaffected in the presence of IGF-I. The origin of this divergent effect on cell signaling is unknown, but it would be reasonable to suggest that this could be due to IGF-induced activation of certain tyrosine phosphatases in the cell, which might dephosphorylate the activated PDGFR at specific sites responsible for the recruitment of PI3K. This hypothesis, however, should be tested in the future.

Although several studies have shown the importance of MAPK and PI3K pathways induced by PDGF and IGF-I in human and rat HSCs, ${ }^{44-47}$ the role of PLC $\gamma_{1}$ signaling pathway has not yet been 
established. It is well known that certain mitogens, including PDGF, elicit breakdown of phospholipids in cell membranes via activation of PLC $\gamma_{1}$. PLC $\gamma_{1}$ then results in a rapid accumulation of diacylglycerol and inositol phosphates with corresponding increase of cytoplasmic $\mathrm{Ca}^{2+}$ levels and subsequent activation of several protein kinase $C$ isoforms, which can alternatively activate MAP kinases through a Ras-independent pathway. ${ }^{15,42,48}$ The data of the present study demonstrate that in LMFs PLC $\gamma_{1}$ is a key signaling element that plays a pivotal role during mitogenic response. Inhibition of PLC was associated with a substantial reduction of both PDGF- and IGF-I-induced mitogenic activity, although in LMFs PLC $\gamma_{1}$ was phosphorylated only in response to PDGF-BB, but not to IGF-I. It can be speculated that IGF-I can also activate other PLC isoforms, which were not studied in the current work. Indeed, PLC $\beta$, which is involved in cell signaling mediated by G protein-coupled receptors, usually is not activated by receptor tyrosine kinases. However, it has been demonstrated that in certain cells IGF-IR associates with G protein, and ligand occupancy of the IGF-IR is accompanied by increased association with $\mathrm{G} \alpha_{i}$ subunit but decreased association with $\mathrm{G} \beta$ subunit. ${ }^{49}$ Dissociated $\mathrm{G} \beta / \gamma$ complex is known to bind and activate PLC $\beta$. Therefore, abrogation of IGF-I-induced proliferation by non-selective PLC inhibitor can be also due to inhibition of PLC $\beta$ that has not been examined in the present study. Taken together, these results presumably point to an essential role of PLC isoforms in the cell and imply that mitogenic and antiapoptotic effects of IGF-I cannot overcome a loss of PLC activity. This speculation is supported by in vivo data, which have demonstrated that homozygous deletion of several PLC genes in mice caused embryonic lethality at very early stages. ${ }^{48}$ A quintessence of the present study was the finding that inhibition of the IGF-IR kinase considerably impaired the tyrosine phosphorylation of PLC $\gamma_{1}$ induced by PDGF-BB. Therefore, the PDGFR requires a functional IGF-IR for full activation of PLC $\gamma_{1}$. However, the mechanism of this inter-receptor cooperation remains a goal of further studies.

In conclusion, the presented data demonstrate that the IGF-IR and PDGFR via complex interactions play important roles in proliferation of rat LMFs. It can be speculated that in the healthy liver initiation of fibrogenesis is repressed through continuous exposure of LMFs to high concentrations of IGF-I that results, on one hand, in downregulation of the IGF-IR and its principal docking protein, IRS-1, and, on the other hand, in inhibition of expression and phosphorylation of the PDGFR $\alpha$ with subsequent suppression of some downstream signaling events. During chronic liver injury, however, the expression of PDGF and its receptors positively correlated with the extent of fibrosis. From this point of view, it can be speculated that increased expression of both PDGF and its receptors might result in stabilization and further upregulation of the IGF-IR in LMFs. The restoration of optimal IGF-I receptor number and sensitivity to IGF-I with subsequent induction of mitogenic activity in LMFs might be involved in the initiation of the fibroproliferative processes in the liver. A cooperation between the IGF-IR and PDGFR facilitates cell signaling induced by PDGF, and the increasing number of PDGF and IGF-I receptors in LMFs finally results in a perpetuation of fibroproliferative response during ongoing liver injury. The data presented herein point to an important role of IGF-I and PDGF during liver fibrogenesis and indicate these growth factors as attractive targets in antifibrotic therapy.

\section{Acknowledgements}

This work was supported by grants from the Deutsche Forschungsgemeinschaft (Scha 700/1-2 and GRK 335) and the Georg-August-Universität Göttingen (Schwerpunktförderung Onkologie). The excellent technical assistance of Ms S Zachmann is highly appreciated. We are indebted to Drs LeRoith and Roberts (NIDDK, National Institutes of Health, Bethesda, MD) for providing rat IGF-IR cDNA.

\section{References}

1 Ramadori G, Saile B. Portal tract fibrogenesis in the liver. Lab Invest 2004;84:153-159.

2 Bataller R, Brenner DA. Liver fibrosis. J Clin Invest 2005;115:209-218.

3 Knittel T, Kobold D, Saile B, et al. Rat liver myofibroblasts and hepatic stellate cells: different cell populations of the fibroblast lineage with fibrogenic potential. Gastroenterology 1999;117:1205-1221.

4 Knittel T, Kobold D, Piscaglia F, et al. Localization of liver myofibroblasts and hepatic stellate cells in normal and diseased rat livers: distinct roles of (myo-) fibroblast subpopulations in hepatic tissue repair. Histochem Cell Biol 1999;112:387-401.

5 Cassiman D, Libbrecht L, Desmet V, et al. Hepatic stellate cell/myofibroblast subpopulations in fibrotic human and rat livers. J Hepatol 2002;36:200-209.

6 Pinzani M, Rombouts K. Liver fibrosis: from the bench to clinical targets. Dig Liver Dis 2004;36:231-242.

7 Novosyadlyy R, Tron K, Dudas J, et al. Expression and regulation of the insulin-like growth factor axis components in rat liver myofibroblasts. J Cell Physiol 2004;199:388-398.

8 Saile B, DiRocco P, Dudas J, et al. IGF-I induces DNA synthesis and apoptosis in rat liver hepatic stellate cells (HSC) but DNA synthesis and proliferation in rat liver myofibroblasts (rMF). Lab Invest 2004;84: 1037-1049.

9 LeRoith D, Werner H, Beitner-Johnson D, et al. Molecular and cellular aspects of the insulin-like growth factor I receptor. Endocr Rev 1995;16:143-163.

10 Rubin R, Baserga R. Insulin-like growth factor-I receptor. Its role in cell proliferation, apoptosis, and tumorigenicity. Lab Invest 1995;73:311-331. 
11 Clemmons DR, Shaw DS. Variables controlling somatomedin production by cultured human fibroblasts. J Cell Physiol 1983;115:137-142.

12 Clemmons DR. Multiple hormones stimulate the production of somatomedin by cultured human fibroblasts. J Clin Endocrinol Metab 1984;58:850-856.

13 Rubini M, Werner H, Gandini E, et al. Platelet-derived growth factor increases the activity of the promoter of the insulin-like growth factor-1 (IGF-1) receptor gene. Exp Cell Res 1994;211:374-379.

14 DeAngelis T, Ferber A, Baserga R. Insulin-like growth factor I receptor is required for the mitogenic and transforming activities of the platelet-derived growth factor receptor. J Cell Physiol 1995;164: 214-221.

15 Heldin CH, Ostman A, Ronnstrand L. Signal transduction via platelet-derived growth factor receptors. Biochim Biophys Acta 1998;1378:F79-F113.

16 Lee KH, Bowen-Pope DF, Reed RR. Isolation and characterization of the alpha platelet-derived growth factor receptor from rat olfactory epithelium. Mol Cell Biol 1990;10:2237-2246.

17 Herren B, Weyer KA, Rouge M, et al. Conservation in sequence and affinity of human and rodent PDGF ligands and receptors. Biochim Biophys Acta 1993; 1173:294-302.

18 Seglen PO. Preparation of rat liver cells. 3. Enzymatic requirements for tissue dispersion. Exp Cell Res 1973;82:391-398.

19 Scharf J, Ramadori G, Braulke T, et al. Synthesis of insulinlike growth factor binding proteins and of the acid-labile subunit in primary cultures of rat hepatocytes, of Kupffer cells, and in cocultures: regulation by insulin, insulinlike growth factor, and growth hormone. Hepatology 1996;23:818-827.

20 Hartmann H, Schmitz F, Christ B, et al. Metabolic actions of insulin-like growth factor-I in cultured hepatocytes from adult rats. Hepatology 1990;12: 1139-1143.

21 Knook DL, Sleyster EC. Separation of Kupffer and endothelial cells of the rat liver by centrifugal elutriation. Exp Cell Res 1976;99:444-449.

22 Knittel T, Janneck T, Muller L, et al. Transforming growth factor beta 1-regulated gene expression of Ito cells. Hepatology 1996;24:352-360.

23 Chirgwin JM, Przybyla AE, MacDonald RJ, et al. Isolation of biologically active ribonucleic acid from sources enriched in ribonuclease. Biochemistry 1979; 18:5294-5299.

24 Caufriez A, Reding P, Urbain D, et al. Insulin-like growth factor I: a good indicator of functional hepatocellular capacity in alcoholic liver cirrhosis. J Endocrinol Invest 1991;14:317-321.

25 Hattori N, Kurahachi H, Ikekubo K, et al. Serum growth hormone-binding protein, insulin-like growth factor-I, and growth hormone in patients with liver cirrhosis. Metabolism 1992;41:377-381.

26 Buzzelli G, Dattolo P, Pinzani M, et al. Circulating growth hormone and insulin-like growth factor-I in nonalcoholic liver cirrhosis with or without superimposed hepatocarcinoma: evidence of an altered circadian rhythm. Am J Gastroenterol 1993;88:17441748.

27 Moller S, Gronbaek M, Main K, et al. Urinary growth hormone (U-GH) excretion and serum insulin-like growth factor 1 (IGF-1) in patients with alcoholic cirrhosis. J Hepatol 1993;17:315-320.
28 Scharf JG, Schmitz F, Frystyk J, et al. Insulin-like growth factor-I serum concentrations and patterns of insulin-like growth factor binding proteins in patients with chronic liver disease. J Hepatol 1996;25: 689-699.

29 Pinzani M, Milani S, Herbst $\mathrm{H}$, et al. Expression of platelet-derived growth factor and its receptors in normal human liver and during active hepatic fibrogenesis. Am J Pathol 1996;148:785-800.

30 Zhang BB, Cai WM, Weng HL, et al. Diagnostic value of platelet derived growth factor-BB, transforming growth factor-beta1, matrix metalloproteinase-1, and tissue inhibitor of matrix metalloproteinase-1 in serum and peripheral blood mononuclear cells for hepatic fibrosis. World J Gastroenterol 2003;9:2490-2496.

31 Clemmons DR. Variables controlling the secretion of a somatomedin-like peptide by cultured porcine smooth muscle cells. Circ Res 1985;56:418-426.

32 Pinzani M, Abboud HE, Aron DC. Secretion of insulinlike growth factor-I and binding proteins by rat liver fat-storing cells: regulatory role of platelet-derived growth factor. Endocrinology 1990;127:2343-2349.

33 Delafontaine P, Lou H, Alexander RW. Regulation of insulin-like growth factor I messenger RNA levels in vascular smooth muscle cells. Hypertension 1991;18: 742-747.

34 Rosenfeld RG, Dollar LA. Characterization of the somatomedin-C/insulin-like growth factor I (SM-C/ IGF-I) receptor on cultured human fibroblast monolayers: regulation of receptor concentrations by SM-C/ IGF-I and insulin. J Clin Endocrinol Metab 1982;55: 434-440.

35 Conover CA, Powell DR. Insulin-like growth factor (IGF)-binding protein-3 blocks IGF-I-induced receptor down-regulation and cell desensitization in cultured bovine fibroblasts. Endocrinology 1991;129:710-716.

36 Eshet R, Klinger B, Silbergeld A, et al. Modulation of insulin like growth factor I (IGF-I) binding sites on erythrocytes by IGF-I treatment in patients with Laron syndrome (LS). Regul Pept 1993;48:233-239.

37 Hernandez-Sanchez C, Werner H, Roberts Jr CT, et al. Differential regulation of insulin-like growth factor-I (IGF-I) receptor gene expression by IGF-I and basic fibroblastic growth factor. J Biol Chem 1997;272: 4663-4670.

38 Bostedt KT, Schmid C, Ghirlanda-Keller C, et al. Insulin-like growth factor (IGF) I down-regulates type 1 IGF receptor (IGF $1 \mathrm{R}$ ) and reduces the IGF I response in A549 non-small-cell lung cancer and Saos-2/B-10 osteoblastic osteosarcoma cells. Exp Cell Res 2001; 271:368-377.

39 Lee AV, Gooch JL, Oesterreich S, et al. Insulin-like growth factor I-induced degradation of insulin receptor substrate 1 is mediated by the $26 \mathrm{~S}$ proteasome and blocked by phosphatidylinositol 3'-kinase inhibition. Mol Cell Biol 2000;20:1489-1496.

40 Karenberg TA, Fenn A, Sachinidis A, et al. The differential activation of phosphatidylinositol-3 kinase and mitogen-activated protein kinases by PDGF-AA and IGF-I might explain the synergistic effect of the two growth factors on the proliferation of AKR-2B fibroblasts. Exp Cell Res 1994;213:266-274.

41 Thommes KB, Hoppe J, Vetter H, et al. The synergistic effect of PDGF-AA and IGF-1 on VSMC proliferation might be explained by the differential activation of their intracellular signaling pathways. Exp Cell Res 1996;226:59-66. 
42 Pearson G, Robinson F, Beers GT, et al. Mitogenactivated protein (MAP) kinase pathways: regulation and physiological functions. Endocr Rev 2001;22: 153-183.

43 Widmann C, Gibson S, Jarpe MB, et al. Mitogenactivated protein kinase: conservation of a three-kinase module from yeast to human. Physiol Rev 1999;79: 143-180.

44 Skrtic S, Wallenius K, Gressner AM, et al. Insulin-like growth factor signaling pathways in rat hepatic stellate cells: importance for deoxyribonucleic acid synthesis and hepatocyte growth factor production. Endocrinology 1999;140:5729-5735.

45 Svegliati-Baroni G, Ridolfi F, Di SA, et al. Insulin and insulin-like growth factor-1 stimulate proliferation and type I collagen accumulation by human hepatic stellate cells: differential effects on signal transduction pathways. Hepatology 1999;29:1743-1751.

46 Gentilini A, Marra F, Gentilini P, et al. Phosphatidylinositol-3 kinase and extracellular signal-regulated kinase mediate the chemotactic and mitogenic effects of insulin-like growth factor-I in human hepatic stellate cells. J Hepatol 2000;32:227-234.

47 Pinzani M. PDGF and signal transduction in hepatic stellate cells. Front Biosci 2002;7:d1720-d1726.

48 Rebecchi MJ, Pentyala SN. Structure, function, and control of phosphoinositide-specific phospholipase C. Physiol Rev 2000;80:1291-1335.

49 Dalle S, Ricketts W, Imamura $\mathrm{T}$, et al. Insulin and insulin-like growth factor I receptors utilize different $\mathrm{G}$ protein signaling components. J Biol Chem 2001;276: 15688-15695 